\title{
Confronting The Challenges Encountered By Primary School Teachers In The Use Of Technological Devices For Teaching
}

\author{
Dr. Dakoru Osomkume Alfred \\ Department of Curriculum Studies and Educational Technology, \\ Faculty of Education, University of Port Harcourt, \\ Choba, Port Harcourt, Rivers State, Nigeria. \\ Dr. Uduak Idoghor \\ Department of Curriculum Studies and Educational Technology, \\ Faculty of Education, University of Port Harcourt, \\ Choba, Port Harcourt, Rivers State, Nigeria.
}

\begin{abstract}
The paper examined the objectives of primary education in Nigeria as stated in the National Policy on Education. These objectives are seen to be achievable only through the instrumentally of the teachers who are the primary implementers of the curriculum. Furthermore, who a teacher is was also critically examined. In addition, the paper advanced some inevitable qualities of a $21^{\text {st }}$ century teacher, without which the teacher will become a misfit in the classroom. These include having a sound knowledge (mastery) of the his/her subject-matter, being properly trained to teach, openness to innovation, being an in-co-parentis, resourcefulness and being computerate. The importance of the application or integration of technologies in the $21^{\text {st }}$ century was also indicated. The climax of the content of the paper was the challenges facing primary school teachers, especially those in the rural areas. The challenges facing Primary School teachers as advanced include ignorance, technophobia, incomputeracy among others. Finally, recommendations on how to confront these challenges were advanced. Some of which are that teachers should wake up to the challenges of the $21^{\text {st }}$ century by making sure that they get trained, the government should also make provision for teachers to get trained and be retrained, teachers should be given certain incentives to encourage them among others
\end{abstract}

\section{INTRODUCTION}

Teaching and learning in the $21^{\text {st }}$ century are characterized by various challenges as the analog teacher is gradually becoming irrelevant. The teacher in this $21^{\text {st }}$ century should understand that educational technologies are becoming more prominent as the days go by. Therefore, teachers are meant to have a paradigm shift to embrace the available technologies in teaching and learning. It has been observed generally that teachers at higher levels of education, for instance the secondary and tertiary levels seem to be more aware of some of the available technologies than those at the primary school level. Many teachers at the primary school level do not feel challenged enough to integrate the use of those technologies in their teaching. However, their inability to utilize these technologies are due to a lot of challenges which in this paper will be identified and strategies to confront them shall also be advanced. Though, these challenges may be general, but the case of primary school teachers is the focus in this paper.

Key terms: confronting, challenges, primary school teachers and technological devices. 


\section{The objectives of Primary Education in Nigeria}

According to Okere (2010), education is a process, product and a discipline. Consequently, as a process, it is the sum total of all the experiences, whether formal or informal, which a person comes across in the journey of life. Teaching indeed is a process, which at the end results in a product visible in learners' quality.

The FGN (2004) advanced that the goals of primary education in Nigeria are to:

a. inculcate permanent literacy and numeracy, and ability to communicate effectively;

b. lay a sound basis for scientific and reflective thinking;

c. give citizenship education as a basis for effective participation and contribution to the life of the society;

d. mould the character and develop sound attitude and morals in the child;

e. develop in the child the ability to adapt to the child's changing environment.

f. give the child opportunities for developing manipulative skills that will enable the child function effectively in the society within the limits of the child's capacity; and

g. provide the child with basic tools for further educational advancement, including preparation for trades and craft of the locality.

Critically examining the above goals, it is evident that the teacher is saddled with a highpowered responsibility to make sure that these goals are achieved to the letter. Being the primary implementer of any curriculum, teachers must stand up to this responsibility and make sure that they deliver the goods. Though the goals are lofty and pleasant, they cannot be achieved if our teachers at this level remain ill-equipped and unprepared.

\section{WHO IS A TEACHER?}

A teacher may be defined as a trained person, male or female, young or old who is the primary implementer of a curriculum at any given level, who takes charge of making learners to have a change in behaviour as a result of exposure to interaction with learning content through facilitating or imparting such. A primary school teacher therefore, is one who accomplishes the above at the primary school level.

\section{Inevitable Qualities of the $21^{\text {st }}$ Century Teacher}

Amanda (2006) stressed that educational practices and the structure that supports them must change in order to ensure that the citizens of the future- that is our school children of the present $21^{\text {st }}$ century can exist and grow in a world characterized by change.

The following are some of the qualities a teacher should possess in the $21^{\text {st }}$ century:

$\checkmark$ Sound knowledge of subject matter (mastery): It is expected that a teacher at any level should have sound knowledge or full grasp of the subject matter he or she is teaching. It has been reported that some teachers go into a class to teach a particular concept or subject matter but end up being taught by those they were supposed to teach. This is an academic fraud and intellectual depravity.

$\checkmark$ Properly trained to teach: The $21^{\text {st }}$ century teacher must be properly trained to teach. This is where a lot of teachers are lacking. Many teachers in our schools are not properly trained to teach. In fact, some are not trained at all. It is even worse when some teachers are mandated to teach subjects they know little or nothing about. It is expected that the $21^{\text {st }}$ century teacher be properly trained with all they are required to use in the classroom. It is even worse in private schools, where some proprietors and proprietresses compel teachers to teach subject areas they are not specialists. An English teacher can be asked to teach Government, C.R.K. and even Social Studies in 
addition to the English Language he or she is teaching. This is an aberration and a superlative abnomer.

$\checkmark$ Openness to innovation: A teacher in the $21^{\text {st }}$ century must have an open mind to technological innovations in teaching and learning. Very many teachers still teach the same contents the same way they taught twenty years ago. Some teachers continue to recopy notes or transfer notes from year to year. This is like living in the past. $21^{\text {st }}$ century teachers must embrace novel ways of content delivery. They must spice their content delivery with new or innovative approaches.

$\checkmark$ In-loco-parentis: This term means that the teacher should act as a parent to all the learners under his or her care. Unfortunately, many teachers lack this quality. This is why a teacher can abuse a learner and extend such to his or her parents at home. Some teachers also tag certain learners 'block heads', indicating that such learners do not have the hope of doing well academically. Some teachers do not see the learners they teach as their own children who need their love, care and continuous encouragement.

$\checkmark$ Resourcefulness: A teacher in this $21^{\text {st }}$ century must be resourceful. He or She must go the extra mile to make sure that learners under him or her are not starved of adequate information and materials during the teaching - learning session. A resourceful teacher will spend his or her money in improvising materials. This also demands some level of skillfulness. It also entails making sure that new teaching media are also integrated in teaching.

$\checkmark$ Computeracy: This quality cannot be optional in the $21^{\text {st }}$ century. Every teacher must be computer compliant and competent in order to be able to use various teaching technologies in content delivery. However, it is very sad to observe that very many teachers, especially in very remote areas do not even know how to power a computer. It is even more grievous to reveal that there are still lecturers in higher institutions of different kinds who still lack this all-important skill. If some lecturers still lack this quality, then there are thousands of teachers at the secondary and primary levels who are deficient in this regard.

The above qualities and more are inevitable if the $21^{\text {st }}$ century teachers are to utilize available teaching technologies in the teaching and learning process.

\section{The importance of utilizing teaching technologies in the $21^{\text {st }}$ century classroom}

The term 'technology' is a Greek derivative from two words "techne" and "logia". The former refers to art, craft, skill, etc, while the latter refers to study, science, etc. therefore, Nwachukwu (2008) explained that technology involves systems, organizational patterns, procedures, various forms of analysis, research and development. Furthermore, that technology is a factor that has greatly influenced educational change and innovation in Nigeria.

Teaching in the $21^{\text {st }}$ century is very tasking. The utilization of various teaching technologies by teachers has tremendous benefits. These benefits underscore the importance of it. These include:

1. Teachers' possession of broader views about concepts treated: The $21^{\text {st }}$ century has provided teachers with various means of content delivery and access to information. Therefore, teachers who avail themselves the opportunities provided by these teaching technologies have a broader spectrum of their content delivery in the classroom.

2. Provision of opportunity to collaborate: Technology has provided various platforms for teachers in the same field to interact, collaborate or connect to get new innovations in their area of specialization. Therefore, teachers on the same platform can be kept updated. 
3. Raising and sustenance of learners' interest: Utilizing various teaching technologies helps to arouse leaners' interest in the class and also sustain it till the lesson period is over.

4. Concretization of concepts: When lessons are presented in a very abstract manner, learners easily forget such concepts taught. For instance, many teachers at various levels still teach the same way they have always taught the concept of nouns. Instead of regurgitating the same ancient definition over the years, just a simple presentation of a video of various nouns will make them internalize the concept and learners can equally give their own definition having viewed the video.

5. Enhancement of teacher-learner productivity: The utilization of technology in the classroom helps the teacher to achieve his or her set objectives faster and also helps the learners to achieve more. The explanation that would have taken thirty minutes can be done within ten minutes through the use of pictures, static or motion as the situation may require.

Though there are a lot of benefits attached to the utilization of various teaching technologies, there are so many challenges facing the primary school teacher, especially in remote areas. Some of these challenges are presented below.

\section{Major challenges facing primary school teachers in remote areas}

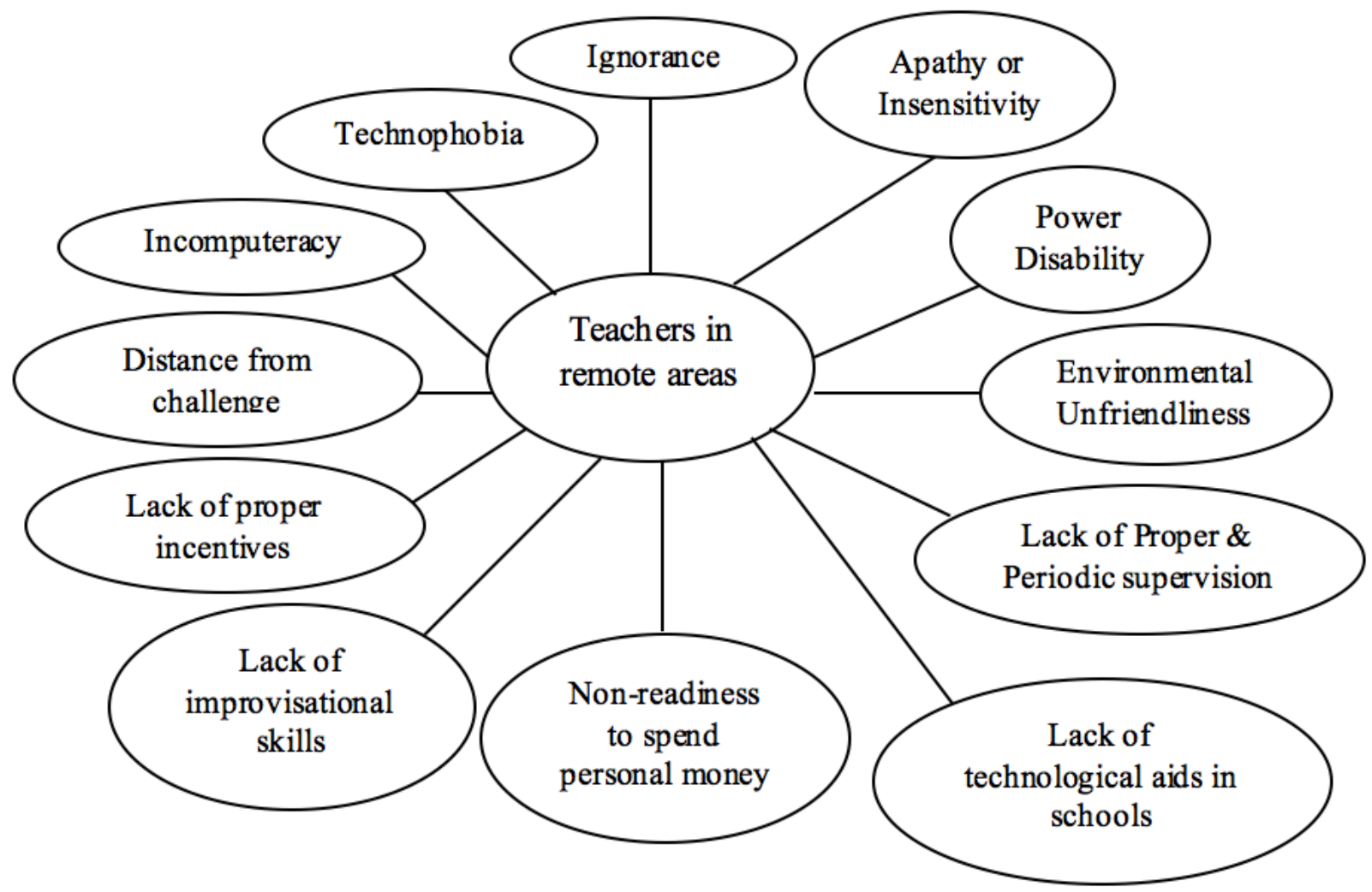

- Ignorance: Many primary school teachers are not aware of available technologies which can be applied in the classroom.

- Technophobia: Many teachers in remote areas think that technological advancement apples more to those in the city or urban areas. So, they even fear the term technology. They are afraid of the use of technology and view it as being esoteric.

- Incomputeracy: It is sad to say that up till this moment, many teachers at all levels are not still computerate. It is very difficult to operate effectively in this $21^{\text {st }}$ century 
without an adequate or appreciable knowledge of the computer. Many teaching technologies are obviously computer-based. This is a very serious challenge.

- Distance from challenge: Many primary school teachers are not challenged by their learners, so, they continue with their old teaching media. The situation is different from city school, where children are more exposed to technology and where the teacher can be under tension if he or she does not upgrade his or her knowledge. Children in remote areas are alienated from technological devices that enhance their personal study before coming to the school. Therefore, it is very difficult for the teacher to be challenged by his or her pupils in the classroom.

- Lack of incentives: many teachers in remote areas feel abandoned, so, they find it difficult to put in their best in the classroom. They feel that those who are enjoying are who are well treated and kept in the city should put in their best in the classroom.

- Lack of improvisational skills: Many teachers depend on whatever the school provides for them to use in teaching. Where the materials or devices to be used are absent, they teach without making any alternative provision. This is one of the challenges in using educational technologies in the classroom.

- Non-readiness to spend personal money: A 21 $1^{\text {st }}$ century teacher in Nigeria must be ready to spend his or her personal money to make his or her lesson more productive or effective. Apart from certain private schools, may government schools have great lack of instructional materials, especially high-tech materials. Some our children have never seen the computer physically. So, far the teacher to use such materials or gargets, he or she has to spend from his/her pocket. This, most teachers are not ready to do. Most teachers feel that their salaries are not even enough for their families, why then should they spend money upgrading themselves personally for learners' benefit.

- Lack of technological aids in schools: Many schools do not even have enough seats for the pupils to sit. In some remote areas, pupils take their seats along with them each day as they are going to school. In some schools, the parents are asked to prepare or provide lockers for their children for the period they will remain as pupils in the school. So, if ordinary seats are not provided, is it instructional materials or technological devices that they can provide?

- Lack of proper periodic supervision and retraining of teachers: The complacency $f$ many teachers in the remote areas is as a result of the lack of periodic and proper supervision of teachers in the classroom. If the government through the Ministry of Education does this regularly, the teachers will make sure that they make use of some of the available technologies in their content delivery. Also, some teachers remain in remote areas for several years without being retrained to meet up with current teaching challenges. They are not also trained on how to use some common technological devices in teaching the subject(s) they teach.

- Environmental unfriendliness: Certain remote areas are far from towns or the capital. Many of these villages are in the riverine areas and creeks where people will remain in the boat for hours before they arrive their destinations. In some areas, the moment you miss the boat that day, you will not be able to travel for that day. Some children in such communities have never seen a car physically and this also affects their reasoning. Consequently, even classroom interaction is affected because of the unfriendly nature of the environment.

- Power disability: Very many remote communities in do not have power supply generally. However, few individuals have small generators (I pass my neighbour) to help them have light and watch the television. In the schools, there is no provision made in this regard. Therefore, it becomes a major issue to use teaching technologies that require electric power supply. 
- Apathy or insensitivity: Many teachers in remote areas are characterized by a feeling of disinterestedness in the use of technology in teaching. This insensitivity is what has made many teachers not willing to embrace technology in teaching. If a teacher is actually interested in the use of technology, he or she will go the extra mile to acquire the requisite skills needed for content delivery in his or her subject area.

\section{RECOMMENDATIONS}

Having identified the dozen-fold challenges encountered by primary school teachers in the use of teaching technologies, the following are recommended:

(i) Individual teachers should awake to the challenges of being a teacher in the $21^{\text {st }}$ century. There should be quest for knowledge at all cost.

(ii) No teacher in the $21^{\text {st }}$ century should wait for the government to provide all the materials or technologies he or she needs to teach. Every teacher should spend money to get some basic computer skills and also buy a computer for himself or herself.

(iii) The government should organize computer training programmes for all teachers. This should be made compulsory and any teacher who misses any of such programmes should be penalized. In doing this, free transportation and accommodation for the period of training should be provided. Teachers should also be given incentives for participating in such programmes and certificates should also be awarded.

(iv) Apart from the general computer training, specialists in different fields with technological know-how on the use of available teaching technologies in various subject areas should be contracted to teach teachers in their various fields regularly.

(v) The government should encourage various service providers and communication network companies to also install their masts in the remote areas to enable those in such areas make use of cell phones and also have internet access. This will encourage teachers in the remote areas to get android phones and also access the internet.

\section{References}

Amanda, C. (2006). Innovation and changes in education. Retrieved from http://www.php.inianna.edu/rreigelut/2.1.2sys.htm.

Federal Republic of Nigeria (2004). National policy on education, Lagos Government Press.

Nwachukwu, E.C. (2008). Information and communication technology in education, challenges in the $21^{\text {st }}$ Century. Multidisciplinary Journal of Research Development. 10(5)

Okere, N.A. (2010). Problems and Prospects of Use of ICT in Nigeria Educational Institutions. Issues on Contemporary Nigeria Education. (1) 105-113. 